\title{
Variáveis lingüísticas e de narrativas no distúrbio de linguagem oral e escrita $* * *$
}

\author{
Linguistic and narrative variables in oral and written language \\ disorder
}

\author{
Liliane Perroud Miilher* \\ Clara Regina Brandão de Ávila**
}

*Fonoaudióloga. Aprimoramento em Distúrbios Psiquiátricos da Infância pelo Departamento de Fisioterapia, Fonoaudiologia e Terapia Ocupacional da Faculdade de Medicina da Universidade de São Paulo. Endereço para correspondência: Rua Ibraim Habib, 13 - Osasco - SP - CEP 06040400 (li_miilher@hotmail.com).

**Fonoaudióloga. Doutora em Distúrbios da Comunicação Humana pela Universidade Federal de São Paulo. Professora Adjunta do Curso de Fonoaudiologia da Universidade Federal de São Paulo.

***Trabalho Realizado no Núcleo de Investigação dos Transtornos da Leitura e da Escrita da Disciplina de Distúrbios da Comunicação Humana Departamento de Fonoaudiologia Universidade Federal de São Paulo.

Artigo de Pesquisa

Artigo Submetido a Avaliação por Pares

Conflito de Interesse: não

Recebido em 05.05.2005.

Revisado em 28.06.2005; 21.11.2005 21.03.2006; 11.05.2006; 14.07.2006 Aceito para Publicação em 14.07.2006.

\begin{abstract}
Background: a study of linguistic and narrative variables in oral and written language disorder. Aim: to characterize the linguistic and narrative productivity, oral and written productions, of scholars with oral and written language disorder. Method: oral and written narrative productions of 30 scholars from public schools (male and female aged 7 to 13 years) were compared. These individuals were grouped as follows: Research group (15) and Control group (15). Samples of oral and written narratives of the story "Little Red Riding Hood" were collected. Comparative analyses were made between the oral and written productions - intragroup (t Student Test and Wilcoxon Test) and intergroup (t Student Test and Mann Whitney Test) - according to the following linguistic variables: total number of words, of nouns, of verbs, of verbs in the past tense, of adjectives, of time markers, of complete statements, of incomplete statements and of reported episodes. Narratives were also compared according to the presence of episodes. Results: differences were observed between the oral and written productions for the research group regarding the total number of produced words $(p=0.018)$ and the total number of produced verbs $(p=0.030)$. The use of time markers such as before $(\mathrm{p}<0.001)$, then $(\mathrm{p}<0.001)$, when $(\mathrm{p}<0.001)$, and after $(\mathrm{p}=0.003)$, and the number of reported episodes, also indicated statistical differences when comparing the groups. Conclusion: The following variables characterized the research group: longer extensions of oral lexical productivity when comparing these to the written productions, less frequent use of time markers and fewer number of certain episodes in the written modality.
\end{abstract}

Key Words: Language Development Disorders; Dyslexia; Linguistic.

\section{Resumo}

Tema: estudo das variáveis lingüísticas e da narrativa no distúrbio da linguagem oral e escrita. Objetivo: caracterizar a produtividade lingüística e de narrativa, de narrações orais e escritas de escolares com distúrbio da linguagem oral e da escrita. Método: compararam-se as narrativas orais e escritas de 30 escolares da rede pública dos sexos masculino e feminino, com idades variando entre 7 e 13 anos, agrupados segundo: Grupo pesquisa (15) e de controle (15). Foram coletadas amostras de narrativa oral e escrita dos trinta escolares, obtidas a partir do reconto história infantil "Chapeuzinho Vermelho". Realizaram-se análises comparativas entre a modalidade oral e a escrita, intragrupos (Teste t de Student e Teste de Wilcoxon) e intergrupos (Teste t de Student e Teste de Mann Whitney), segundo as variáveis lingüísticas: números totais de palavras, de substantivos, de verbos, de verbos no passado, de adjetivos, de marcadores temporais, de enunciados completos, de enunciados incompletos e de episódios relatados, e segundo critérios de análise de narrativa considerando-se as presenças dos episódios. Resultados: foram observadas diferenças entre as modalidades oral e escrita no grupo com distúrbio quando se analisou o número total de palavras $(\mathrm{p}=0,018)$ e o número de verbos $(\mathrm{p}=0,030)$. Além disso, o uso dos marcadores temporais antes $(p<0,001)$, então $(p<0,001)$, quando $(p<0,001)$, e depois $(p=0,003)$, e o relato de episódios também mostraram diferenças estatísticas na comparação entre os grupos. Conclusão: maior produtividade lexical oral se comparada à escrita, uso menos freqüente de marcadores temporais e menor número de certos episódios relatados na modalidade escrita, caracterizaram os escolares com distúrbios. Palavras-Chave: Transtornos do Desenvolvimento da Linguagem; Transtorno do Desenvolvimento da Leitura; Lingüística. 


\section{Introduction}

Oral language development starts as soon as the child is born. Since this moment child is exposed to oral code and starts to get familiar to the language sounds and starts to articulating them. Later, about the age between 05 and 7, the child begins to formally learn written language. Despite the intrinsic differences between the two modalities of communication, there are common issues (Storch and Whitehurst, 2002) which have called research's attention and which have justify the statement that written language is a continuum of the oral language (Santos and Navas, 2002). It is supposed that this development naturally occurs, in a predict rhythm. Nonetheless, the development of the written language is influenced by child's life experience concerning rending and writing practice in his family's context (Medeiros and Silva, 2002; Gonçalves and Dias, 2003; Spinillo and Simões, 2003; Muñoz et al., 2003; Padovani et al., 2004).

Among child's oral language skills, talking about events (narrative) is one of the most important. From connecting words and form temporal perception of events, child starts to explore his own experiences, inaugurating the protonarrative period (Artoni, 2001). This ability improves and the child is not only able to tell his experience but also to retell stories and to use his imagination to creat imaginary scenes and characters (Brockmeier and Harré, 2003; Shiro, 2003). According to Geraldi (2002), the child is not only learning a language but also to efficiently using it.

The ability to tell stories presented by the child improves and gets more sophisticated and more elaborated to then be transferred to written language (Windsor et al., 2000). From randomly grouping letters, writing becomes more concrete, and coherent and cohesion outputs supports oral thoughts. The development of writing events is related to the child's previous experience to oral model exposure and to narrative stimulation, through the taught of story category, which may lead to changes in written language repertoire (Maranhe, 2004). Geraldi (2003) studied written texts elaborated by scholars and pointed that those resembled to the oral speech; likewise they pursued child's previous experience.

Nevertheless, some children present delay or disorder to acquire language. Those disorders manifest in different areas of the oral language, in which the subjacent process, such as the linguistic elements, tend to similarly respond to the learning and to the development of written language. Reading and writing disorders are frequently based on oral language disorder (ASHA, 2006) and are manly characterised by difficulties in either words, statements and texts reading comprehension or integrating the meaning of words and sentence in the text (Snowling, 2006). Santos and Navas (2002) also argue that difficulties in written language acquisition or development are presented in children who have phonological processing and writing and reading comprehension disorder. Those children's oral narrative is studied in this study.

Several authors have perused the narrative comparing the abilities and competencies in children with and with not language disorder (Gillam and Johnston, 1992; Oetting and Howr, 1997; Kaderavek and Sulzby, 2000; Scott and Windsor, 2000; Conti-Ramsden, 2003). However, the studies are still in progress. The researches may contribute to understand children's construction of knowledge and their world apprehension schema. The study of the linguistic ability and productiveness may be a start in on.

During narrative production, the child can simply tell the story but not interfere with them. Regularly, he uses verbs in past tense (Koch and Travaglia, 2003).

The use of verbs in past tense indicates that the story occurred in some indeterminate time in past. It strongly occurs in popular and fairy tales when "once upon a time" is always employed (Eco, 1999).

The study of narrative production and the past tense verbs use, which is an important element for narrative structure identification, in children's with and with no language disorder are previously done (Oetting and Horohov, 1997) through the presentation of regular and irregular verbs to the children. Studies argued about the employment of past tense in invented verbs. Results showed the same past pattern used by the target group as by MLU-control group. Another study (ContiRamsden, 2003), comparing atypical children with language disorders, verified they have significant lower performance in tasks which requires past tense uses.

Beyond time term, temporal adverbs are used in children's oral narrative, such as connectors, meaning, narrative sequence organiser. The regular adverb employed by 06 and 07 -year-old children 
is "after" followed by "when". The term "when" attests ruptures in the narrative, addressing a new state, "so" indicates a closure and a new beginning, 'after" is an anaphoric verb which in the same time reffers to an old statement and a new announcement (Souza, 1996). The use of the terminology "so" seems to precede the others during linguistic development; nevertheless, its distributions is less usual than the term "and" (Monnerat, 2003). The knowledge about children's temporal adverb employment requires more research.

Scholars who have learning difficulties during early language development may continuing to present then in written narrative tasks (Bishop and Clarkson, 2003; Nathan et al., 2004). Children with or with not language disorders tell narratives but not with the same skills. Oral narrative of small children with or with not language disorders do not differ from using the story structure (begin, middle and end) nor the verbal tense (present, past and future), except by past tense: children with language disorder use less often past tense verbs (Kaderavek and Sulzby, 2000).

When comparing oral and written narrative produced by the same child, there are differences in content organisation: Oral narrative shows a larger number of local interconnections while written narrative a greater number of global interconnections (Gillam and Johnston, 1992). The first one refers to explicit linguist forms in oral text, which indicates inner, and inter sentential. The second one, on the other hand, indicates a relation between the narrative elements, which make the text richer. Overall, the local interconnections are microstructures, and, therefore, cohesive; and global ones are macrostructure and related to coherence (Pinheiro, 2003; Norbury and Bishop, 2003).

The study of the text structure demonstrates that the cohesion is more directly connected to macro structural organisation during its construction (Spinillo and Martins, 1997). It comprises the shared knowledge, the new information, the justifications and the conclusion. The cohesion is the text linear manifestations, transmitted by the verbal code. A rule to have it is the attachment between periods and paragraphs (Strong and Shaver, 1991). What makes a text differ to the derangement-displayed sentences is its textually. This involves coherence, cohesion, intentionally, acceptance, situational, informatively and intertextual. The first ones are related to conceptual and linguistic elements and the five others to the pragmatic factors involved in the text construction (Felisbino, 2001, Dijk, 2006).

The comparison between scholars' oral and written narrative, with or with not language disorders, revels a larger number of grammatically unacceptable units, produced by children with language disorders. That also is presented in written production, but in a different form (Gillam and Johnston, 1992; Fey et al., 2004)..

Seven variants used to the text production were described (percentage and total number of utterances; mean of words by period; mean of subordinate period by unit, mean of numbers of words by subordinate period, percentage of grammatical units and complete cohesive element), which were distributed in two segments: global organisation (referring to epic construction of the narrative), and inner and inter structure of the sentence (about productiveness factors). The variants in the second element were considered more effective during groups' discrimination, in a presence of a language disorder (Liles et a.1., 1995).

Children with language disorder may develop narrative macrostructure. However, this skills is nor usually enough elaborated and flexible to reading and writing learning. Overall, children present more difficulty to infer, which demands information integrity, and to predict about someone's though (Norbury and Bishop, 2003). Concerning microstructure, they present difficulties in selecting cohesive and syntactic schemas and in using more co-ordinates then subordinate sentences; and, therefore, their written text productions are lesser coherence and cohesion (Sayeg-Siqueira, 1990).

Studies with regard to several parameters related to productivity (concerning fragment measures, for instance distribute a criteria to a chosen unit, such as statements or sentences), to fluency, to lexical diversity and to grammatical complexity facilitate to differ groups of children with or whit no language disorder. Scholars with language difficulties have lower performance productiveness and grammatical complexity (Scott and Windsor, 2000). The authors requested children to make a narrative and a speech in both written and oral modalities. The identification of grammar mistakes was an efficient procedure to differ the groups. The written modality showed more mistakes and less production than oral one in both groups.

It is important to mention that before the student become competent in programming and producing his own stories, he has a period, in which he 
apprehend cultural schemas of the narrative. According to Dijk (2006) language users build up a model, a fact or a situations representation about the text, which permits him to create a cohesive and a coherent text and to comprehend it. For that, infant stories shared by teachers and parents are especially important. Those will lead to a more elaborated plot, that is necessary to the comprehension and to the creation of his own narratives (Brockmeier and Harré, 2003). The early difficulties presented to oral language may influence later on written production.

The knowledge regards oral language development makes possible a clear and a conclusive understanding in regard to how children creating their narrative.

The possibility to measure and to quantify linguistic characteristics in oral and written narratives helps to clarify the process of language acquisition and development capacity in those population and in children who have oral language disorders; and therefore, written language disorders.

In addition to the differences between oral and written production exposed in literature, other ones may be observed by the clinical approach. It is verified that spontaneous written narratives, produced by scholars, are extreme overworked, poor and incomplete (Santos and Navas, 2002). Several times the final result prevents to compare them to the one produced by regular students. For this reason, in order to get the homogeneity, which lead comparison, students from this study areas requested to orally and written tell the ordinary tale "Red Hood" (Ferreiro et al, 1996).

Talking into account the possibility of these children have presented or present some oral language disorder, it may expected that their oral and written narrative show some inadequacies. It is perceive that oral productions use repetition as a text elaboration strategy, either as a cohesive mechanism or a turn (Koch, 2003). Speech and writing are two modalities of the same language and, despite using the same linguistic system, they have their own characteristics (Koch, 2003).. Those characteristics may influence on the frequency of linguistic items on oral communications, when comparing to the written one. Those differences may also be observed when analysing oral and written productions of individuals with oral or written language disorders.

Based on the statements above, this study aimed to study the characteristic of the linguistic productive and of the narrative, from oral and written production in scholars diagnosed with oral and written disorder.

\section{Method}

This study was accepted and approved by the Ethic Committee of the Universidade Federal de São Paulo (Federal University of São Paulo), protocol 0404/03) and the research had started just after the free-consent of the all participants.

\section{Subjects}

Thirty male and female students from 07 to 13 years old, distributed in two groups:

\section{Research group:}

Fifteen patients from Ambulatório de Terapia Fonoaudiológica do Hospital São Paulo/UNIFESP-EPM were selected to this study. All students enrol public mainstream school, from different districts of São Paulo ( $1^{\mathrm{a}}$ to $5^{\mathrm{a}}$ grades) and attend the clinic due to language and oral disorders. All patients complain about or have difficulty regards learning and/or using the reading and writing code. Nevertheless, evaluation performed by the speech and hearing pathologist showed children have oral language disorder, manly characterised by lexicon-semantic restriction and poor syntax use. In the end of the evaluation all children were diagnosed with oral language disorder and reading and writing disorders. Exclusion criteria included: sensorial and/ or cognitive deficits or neurological disorder (table 1).

\section{Control group}

Fifteen students from 06 years and 10 months to 10 years and 4 months with no complains about difficulty in reading and writing learning attested by their teachers participated on this study. All children enrol public school, located in the south of São Paulo, where they attend 1st to 5th grades of elementary school. Subject's selection turned out after selection of the students with no learn and pedagogic difficulties, done by their teacher's. The same exclusion criteria used to Research Group were adopted for this one. (table 2).

\section{Procedures}

Oral and written samples from the thirty school children were collected from the retelling of same child story. The data collecting was performed individually in a silent room in the school or in the ambulatory.

Each child was requested initially to tell the story of "Red Hood". This procedure was used once the 
elaboration of a spontaneous story demands more cognitive resources than the retelling of a known one (Ferreiro et al., 1996). No interruptions, gesture or oral signs were provided during the retelling.

Each story was recorded with a mini Aiwa TPVS485 recorder in a Sony EF-X 60 minutes cassette tape. The oral productions were transcribed canonically.

After the oral production, a white sheet and a black HB no 2 pencil was provided to each school child and they were requested to write the same story previously told.

Each oral production was transcribed and each written production was initially analyzed according the following linguistic variables: total number of words, including all grammatical classes and repeated words (Scott \& Windsor, 2000); total number of substantives; total number of verbs - all verbs in the past or in other verbal tenses were considered; total number of verbs in the past tense; total number of adjectives (Kaderavek \& Sulzby, 2000); number and discrimination of temporal markers: when, then, after and before (Souza, 1996); number of complete enunciates (units with a conjugated verb as the center); number of incomplete enunciates (units without a conjugated verb as the centre, however expressing an idea); number of reported episodes.

Next, the oral productions were transcribed and studied again according to the narrative analysis criteria (Ferreiro et al., 1996). Therefore, the presence of the following episodes were considered in the analysis of each production: 1. Character introduction; 2. Mother asks Red Hood to take cookies to the grandmother; 3 . Red Hood walks through the woods; 4 . The character meets the wolf; 5. Wolf arrives at grandmother's house; 6. Canonic dialogue between wolf and Red Hood; 7 . Introduction of the hunter; 8. Finalization formula.

\section{Statistical method}

For the comparative analysis between the oral and the written modalities of both control and research groups (intra-group comparison) the following statistical tests were used: for parametric variables - Student's t test for paired data, and for non-parametric variables - Wilcoxon test of signalized posts.
The comparative analysis between the control and the research groups in the oral and written modalities (inter-group comparison) was made through the use of the following statistical tests: Student's t test controlled by the Levene's Variance homogeneity test for parametric variables and the Mann Whitney test for non-parametric variables.

The values with an asterisk showed statistical significance. The significance level adopted was 0.05 .

\section{Results}

Comparison between the oral and the written modalities (intra-group analysis).

Table 3 presents the comparison between the linguistic values used in the oral and in the written modalities. In the research group there was a statistical difference when comparing the average use of verbs and the total number of words. In the comparison group there was no statistical difference between the modalities in any of the studied variables.

Table 4 shows that the comparison between the number of episodes of the oral and the written modalities in both groups did not reveal any significant statistical difference.

Comparison between the comparison and the control groups (inter-group analysis).

Table 5 shows that there was no significant statistical difference between the studied linguistic variables when comparing the Research and the Comparison Groups in the oral narrative, except for the variable "temporal markers" that presented statistical difference in the comparison between the groups in the oral narrative. Concerning the comparison between the groups in the written narrative, the only variable that presented statistical difference was the temporal adverb "when".

Table 6 shows that there was no significant statistical difference in the comparison between the episodes presented by the research and the comparison groups in the oral modality. In the written modality, episodes 1 and 3 were more frequent in the research group, and this difference was statistically significant. 
Table 1: Distribution of the students from the Research Group.

\begin{tabular}{c|c|c|c}
\hline \multirow{2}{*}{ AGE (anos) } & \multicolumn{2}{|c|}{ GENDER } & \multirow{2}{*}{ TOTAL } \\
\cline { 2 - 3 } & MALE & FEMALE & \\
\hline 7 & - & 1 & 1 \\
8 & 2 & 1 & 3 \\
9 & 1 & 2 & 3 \\
10 & - & 3 & 3 \\
11 & 2 & 1 & 3 \\
12 & - & - & - \\
13 & 1 & 1 & 2 \\
TOTAL & 6 & 9 & 15 \\
\hline
\end{tabular}

Table 2: Distribution of the students from the Control Group

\begin{tabular}{c|c|c|c}
\hline \multirow{2}{*}{ AGE (anos) } & \multicolumn{2}{|c|}{ GENDER } & \multirow{2}{*}{ TOTAL } \\
\cline { 2 - 3 } & MALE & FEMALE & \\
\hline 6 & - & 1 & 1 \\
\hline 7 & 3 & 2 & 5 \\
8 & 1 & 1 & 2 \\
9 & 3 & 2 & 5 \\
10 & 1 & 1 & 2 \\
\hline TOTAL & 8 & 7 & 15 \\
\hline
\end{tabular}

TABLE 3- COMPARISON BETWEEN THE AVERAGE USE OF THE LINGUISTIC VARIABLES STUDIED IN THE ORAL AND THE WRITTEN NARRATIVES IN CONTROL AND RESEARCH GROUPS

RG: research group; CG: control group; ON: oral narrative; WN: written narrative

Statistical tests: Student 's $\mathrm{t}$ test for paired data

\begin{tabular}{|c|c|c|c|c|c|c|}
\hline \multirow[t]{2}{*}{ Variables } & \multicolumn{2}{|c|}{ RG } & \multirow[t]{2}{*}{ p-value } & \multicolumn{2}{|c|}{$\mathrm{CG}$} & \multirow[t]{2}{*}{ p-value } \\
\hline & $\mathrm{ON}$ & WN & & ON & WN & \\
\hline Substantives & 30,60 & 21,47 & 0,051 & 22,53 & 30,23 & 0,114 \\
\hline Verbs & 16,80 & 8,73 & $0,018^{*}$ & 10,53 & 12,62 & 0,689 \\
\hline Verbs in the past tense & 17,87 & 11,80 & 0,056 & 17,83 & 18,15 & 0,840 \\
\hline Adjectives & 5,00 & 3,93 & 0,316 & 5,27 & 6,15 & 0,470 \\
\hline Complete enunciates & 30,33 & 20,43 & 0,058 & 22,67 & 24,31 & 0,885 \\
\hline Incomplete enunciates & 2,93 & 2,14 & 0,253 & 2,00 & 2,46 & 0,880 \\
\hline Words & 160,33 & 100,33 & $0,030^{*}$ & 122,27 & 141,46 & 0,659 \\
\hline Before & 0,00 & 0,00 & $>0,999$ & 1,50 & 1,00 & 0,500 \\
\hline After & 0,27 & 0,00667 & 0,384 & 1,00 & - & - \\
\hline Then & 0,00 & 0,33 & 0,238 & 4,50 & 1,20 & 0,500 \\
\hline When & 0,33 & 0,27 & 0,582 & 2,00 & 2,13 & 0,749 \\
\hline
\end{tabular}


Pró-Fono Revista de Atualização Científica, v. 18, n. 2, maio-ago. 2006

TABLE 4: COMPARISON BETWEEN THE NUMBER OF EPISODES REPORTED IN THE ORAL AND THE WRITTEN NARRATIVES IN THE RESEARCH AND IN THE CONTROL GROUP.

\begin{tabular}{|c|c|c|c|c|c|c|}
\hline \multirow[t]{2}{*}{ Episodes } & \multicolumn{2}{|c|}{ RG } & \multirow[t]{2}{*}{ p-value } & \multicolumn{2}{|c|}{ CG } & \multirow[t]{2}{*}{ p-value } \\
\hline & $\mathrm{ON}$ & WN & & $\mathrm{ON}$ & WN & \\
\hline 1 & 7 & 8 & 0,564 & 11 & 13 & 0,046 \\
\hline 2 & 10 & 8 & 0,317 & 7 & 6 & 0,317 \\
\hline 3 & 6 & 2 & 0,180 & 6 & 8 & 0,157 \\
\hline 4 & 12 & 10 & 0,317 & 9 & 11 & 0,157 \\
\hline 5 & 15 & 12 & 0,157 & 14 & 10 & 0,317 \\
\hline 6 & 12 & 12 & $>0,999$ & 10 & 11 & 0,317 \\
\hline 7 & 10 & 8 & 0,317 & 10 & 9 & $>0,999$ \\
\hline 8 & 4 & 3 & 0,317 & 6 & 7 & 0,414 \\
\hline
\end{tabular}

RG: research group; CG: control group; ON: oral narrative; WN: written narrative

Statistical tests: Wilcoxon test of signalized posts

TABLE 5: COMPARISON BETWEEN THE SCHOOL CHILDREN GROUPS REGARDING THE STUDIED VARIABLES IN THE ORAL (ON) AND IN THE WRITTEN (WN) NARRATIVES.

\begin{tabular}{|c|c|c|c|c|c|c|}
\hline \multirow[t]{2}{*}{ Variables } & \multicolumn{2}{|c|}{ ON } & \multirow[t]{2}{*}{ p-value } & \multicolumn{2}{|c|}{$\mathrm{WN}$} & \multirow[t]{2}{*}{$\mathrm{p}$-value } \\
\hline & RG & $\mathrm{CG}$ & & RG & CG & \\
\hline Substantives & 30,60 & 22,53 & 0,189 & 21,47 & 30,23 & 0,111 \\
\hline Verbs & 16,80 & 10,53 & 0,182 & 8,73 & 12,62 & 0,188 \\
\hline Verbs in the past tense & 17,87 & 17,83 & 0,905 & 11,80 & 18,15 & 0,137 \\
\hline Adjectives & 5,00 & 5,27 & 0,861 & 3,93 & 6,15 & 0,166 \\
\hline Words & 160,33 & 122,27 & 0,302 & 100,33 & 141,46 & 0,133 \\
\hline Complete enunciates & 30,33 & 22,67 & 0,310 & 20,43 & 24,31 & 0,456 \\
\hline Incomplete enunciates & 2,93 & 2,00 & 0,353 & 2,14 & 2,46 & 0,628 \\
\hline Before & 0,00 & 1,50 & $<0,001 *$ & 0,00 & 1,00 & - \\
\hline After & 0,27 & 1,00 & $0,003 *$ & 0,00667 & - & - \\
\hline Then & 0,00 & 4,50 & $<0,001 *$ & 0,33 & 1,20 & 0,093 \\
\hline When & 0,33 & 2,00 & $<0,001 *$ & 0,27 & 2,13 & $0,003 *$ \\
\hline
\end{tabular}

RG: research group; CG: control group; ON: oral narrative; WN: written narrative Statistical tests: Student's t test controlled by the Levene's Variance Homogeneity test 
TABLE 6: NUMBER OF EPISODES REPORTED IN THE ORAL AND IN THE WRITTEN NARRATIVES.

\begin{tabular}{lllllll}
\hline \multirow{2}{*}{ Episode } & \multicolumn{2}{c}{ ON } & p-value & \multicolumn{2}{c}{ WN } & p-value \\
\cline { 2 - 3 } & RG & CG & & RG & CG & $0,009^{*}$ \\
\hline 1 & 7 & 11 & 0,143 & 8 & 13 & 0,575 \\
3 & 10 & 7 & 0,277 & 8 & 6 & $0,013^{*}$ \\
4 & 6 & 6 & $>0,999$ & 2 & 8 & 0,419 \\
5 & 12 & 9 & 0,240 & 10 & 11 & 0,564 \\
6 & 15 & 14 & 0,315 & 12 & 10 & 0,692 \\
7 & 12 & 10 & 0,417 & 12 & 11 & 0,524 \\
8 & 10 & 10 & $>0,999$ & 8 & 9 & 0,087 \\
\hline
\end{tabular}

RG: research group; CG: control group; ON: oral narrative; WN: written narrative

Statistical test: Mann-Whitney test

\section{Discussion}

Initially, it necessary to remind that all school children from the Research Group looked for the Speech and Hearing Sector with Reading and Writing learning disorders complaints. The diagnostic of such disorders demanded an oral language evaluation in its expressive and comprehensive aspects, in order to enable the identification of alterations related exclusively to the reading and writing mechanisms in the absence of oral communication disorders. The school children evaluations identified comprehension and expression alterations related to the lexical restriction and, mainly to the syntax use. Such alterations were not manifested in the pre-school period, once the complaints were raised only during the school phase.

Studying the linguistic variables, the intragroup comparison revealed that the oral and the written productions of the Comparison Group were similar. Differently, in the Research Group (Table 3), the average number of total words and the number of verbs used in the oral narrative were greater than the ones found in the written narrative, despite the semantic-lexical restrictions identified in the diagnostic process. This result corroborated the Scott and Windsor's (2000) one, in which significant differences were found between the oral and the written narratives, being the written ones less extended than the oral ones. According to Koch (2003) the oral narrative naturally has more repetitions than the written one. Nevertheless, in this study the significant reduction in the use of words, including verbs, in the written narrative may confirm the presence of written language disorders found in the speech-language evaluation of the Research Group.

The study of the linguistic variables of the Comparison Group evidenced similarities between the averages of all variables use when the two modalities of narratives were compared. A similar result was obtained by Kaderavek and Sulzby (2000), that is, no difference was found between the oral and the written narratives of the school children control group concerning the use of linguistic variables.

The initial analysis evidenced that both groups used verbs in the past tense in the two modalities of language and, therefore indicated and characterized their production as narrative structures (Koch \& Travaglia, 2003; Eco, 1999; Oetting \& Horohov, 1997).

Concerning the use and the type of temporal markers, no difference was observed in the frequency of use when comparing the oral and the written productions, in the intra-group comparison. Concerning the absolute number of times that such temporal adverbs were used, the most frequent markers were: "when" and "after" in the oral narrative, differing from Souza (1996) and Monnerat's (2003) findings, and "then", "when" and "after" in the written narrative.

The comparative analysis of the narrative structures of the oral and the written elaborations of each group showed that the total numbers of complete enunciates in the oral and in the written modalities were similar, either in the Research Group 
as in the Comparison Group (Table 5), which corroborated the findings of Fey et al. (2004) who compared the two modalities of narrative language with the number of grammatically correct units. Accordingly, the total number of incomplete enunciates of the oral and the written narratives wasn't different in both groups. These results are different from those indicated in the literature that showed a greater number of enunciates in the oral narrative than in the written one, which presented greater number of global interconnections (Gillam \& Johnston, 1992; Scott \& Windsor, 2000; Koch, 2003, Monnerat, 2003). Apparently, the previous knowledge of the text (the "Red Hood" story), besides having facilitated the data collecting of the written material, may also have influenced this result, making similar the number of enunciates (Ferreiro et al. 1996). Furthermore, the language resources evidenced by the Research Group when narrating orally their stories may also explain this results.

As mentioned before, there weren't studies in the literature using the parameter "number of complete enunciates" in the analysis of oral or written productions as shown in Table 3, that presented similarities between the two narrative modalities in both groups.

The inter-group analysis initially showed that the total number of words (and the number of words studied separately by grammatical class) used by both groups in their oral and written narratives was similar. The results observed in the oral narrative differed from those published in the literature. According to such studies, typical children present better performance in their oral narratives (greater number of words in the narrative structure) than their peers of same chronological age with language disorder (Scott \& Windsor, 2000).

Thus, as observed, there wasn't any difference in the use of grammatical classes by both groups. The numeric comparison between the use of "verbs" and "verbs in the past tense" agreed with other studies (Oetting \& Horohov, 1997; Kaderavek $\&$ Sulzby, 2000). Nevertheless, the absolute values of the verbal tense use disagreed with the literature, that pointed a less frequent use of verbal structures conjugated in the past in relation to the present tense in the research group when compared to the control group (Kaderavek \& Sulzby, 2000; ContiRamsden, 2003). Conversely, in the present study both groups used more verbs in the past tense in both modalities, indicating an understanding of the verbal tense marker use (past) to characterize the narrative as a fact that had already happened (Eco,
1999; Dijk, 2006).

Thus, the inter-group comparison of oral narratives showed that the school children from the Research Group presented worse performance only in the use of temporal markers. Therefore, despite the similarities of the lexical production evidenced by the number of words (independently of the grammatical class), the lesser frequency of temporal adverbs use characterized the group with disorder. Such markers act as sequence organizers, perform text ruptures and plan other narrative enunciations. The lack of use of these markers may produce fluency and text grammatical complexity alterations (Souza, 1996). Thus, this lack may be related to the syntactic operations, once as the other syntactic elements, these markers operate in the micro structural cohesion of the text. The syntactic alterations found in the oral language evaluation of this group of school children may explain this finding.

No significant statistical differences were found when comparing the total number of enunciates of the oral narratives of both groups. The literature evidenced that typical children (of same chronological age) presented greater number of enunciates than children with language difficulties (Scott \& Windsor, 2000; Bishop \& Clarkson, 2003), differently than what was found in this research.

Table 5 indicated that the number of incomplete enunciates of the Comparison Group and the Research Group were similar. Contrarily, the literature showed that children with language problems produced a greater number of unacceptable grammatical units (Gillam \& Johnston, 1992; Fey et al., 2004) and that the difficulties presented by children with language disorders are more evident in the intra-sentential grammatical structure, which would result in a greater number of incomplete episodes (Liles et al., 1995).

The literature also indicated that children with language problems presented greater difficulty in selecting cohesive schemes and use more coordinates than subordinated structures (Liles et al., 1995), that could be expressed by finality, condition and concomitance, time-cause and consequence relations (Sayeg-Siqueira, 1990). Similarly, this study showed that, despite knowing the text previously, the school children group with disorders used less frequently the temporal markers when their oral narrative structures were compared to the comparison group, and this difference was statistically significant (Table 5).

On the other hand, when analyzing comparatively the written narratives, the marker 
"when" was the only one that indicated difference between the groups. This marker operates ruptures in the narrative sequence, demonstrating that typical children have greater facility to work with the break/ continuity aspects, typical of narratives (Souza, 1996), and which was not possible to find in the written narratives of children with learning disorders.

It wasn't possible to identify differences between the performance of school children with Disorders and the Comparison Group concerning the number of reported episodes. Table 6 showed that there was no statistical difference in the reporting of episodes in the oral narrative. There isn't a consensus in the literature regarding this narrative characteristic. Therefore, the similarity of the two groups regarding the number of reported episodes in the oral modality differed from authors who evidenced greater number of episodes reports from the middle of the story than the other ones (Kaderavek \& Sulzby, 2000), and agreed with other studies that did not find significant differences in the narrative episodic structure of children with and without language difficulties (Liles et al., 1995; Norbury \& Bishop, 2003). In this research it was possible to observe significant statistical difference in the report of episodes 1 and 3 between the groups in the written modality. These findings differed partially from the results of Kaderavek and Sulzby (2000), according to which the middle of the story was more reported than the other parts of it, and also differed from Liles et al. (1995) who didn't find significant differences in the narrative episodic structure of children with and without language difficulties.

Finally, it's worth to remind that the result obtained in this study was analyzed according to the linguistic material collected. That is, a known story, which does not demand the same degree of cognitive processing than the elaboration of some

\section{References}

ARTONI, A. L. Caracterização de narrativas de crianças de 5 e 6 anos: correlações entre episódios e ações. 2001. 104 f. Dissertação (Mestrado em Distúrbios da Comunicação Humana) - Universidade Federal de São Paulo, São Paulo.

ASHA. Language based learning disabilities. Rockville: [s.n]. Available at: <www.asha.org/public/speech/disorders/ language-based-learning-disabilities.htm>. Access: 12 Feb. 2006.

BISHOP, D. V. M.; CLARKSON, B. Written language as a window into residual language deficits: a study of children with persistent and residual speech and language impairments. Cortex, Varese, v. 39, n. 2, p. 215-237, abr. 2003 other text modality. Nonetheless, important differences concerning the use of temporal markers were found either in the comparison of the oral as in the written report of the story, demonstrating that the language impairments, specially the written one, affected the performance of the Research Group when narrating their stories, even though the linguistic material was widely known.

Despite the adequacy of the lexical diversity found in the oral narratives of the Research Group, the significant worsening observed in the written modality characterized the performance of the group. The little use or the lack of temporal marker use confirmed the literature reports (Scott \& Windsor, 2000), and also characterized the Research Group performance.

Other studies involving the comparative analysis of the production of different text modalities and styles should be performed in order to confirm, or not, these findings.

\section{Conclusion}

The study of the linguistic variables could show through the comparison of the groups' performances that the group of school children with Oral and Written Language Disorders:

- presented greater number of verbs and, consequently, of enunciates and greater total number of words in their oral narratives when compared to the written ones.

. used temporal markers less frequently in the oral and written modalities, suggesting that the linguistic measures of these markers could help to characterize the group.

. reported certain episodes less frequently in the written modality, suggesting that this parameter of narrative analysis also could characterize the oral and written language disorder in narration activities.

BROCKMEIER, J.; HARRÉ, R. Narrativa: problemas e promessas de um paradigma alternativo. Psicol. Refl. Crít., Porto Alegre, v. 16, n. 3, p. 525-535, set.-dez. 2003.

CONTI-RAMSDEN, G. Processing and linguistic markers in young children with specific language impairment (SLI). J. Speech Lang. Hear. Res., Rockville, v. 46, n. 5, p. 1029-1037, out. 2003.

VAN DIJK, T. A. De la gramática del texto al análisis critico del discurso. Beliar, Buenos Aires, v. 2, n. 6, p. 2040, 1995. Available at: <www.discourse-in-society.org/ beliar-s.htm>. Access: 26 Feb. 2006.

ECO, U. Seis passeios pelo bosque da ficção. São Paulo: Companhia das Letras, 1999. 
FELISBINO, F. Avaliação de produção textual. Ling. (Dis)curso, Tubarão, v. 1, n. 2, 2001. Available at: <www3.unisul.br/paginas/ensino/pos/linguagem/0102/ 11.htm>. Access: 26 Feb. 2006.

FERREIRO, E.; PONTECORVO, C.; MOREIRA, N. R.; HIDALGO, I. G. Chapeuzinho Vermelho aprende a escrever: estudos psicolingüísticos comparativos em três línguas. São Paulo: Ática, 1996.

FEY, M. E.; CATTS, H. W.; PROCTOR-WILlIAMS, K.; TOMBLIN, J. B.; ZHANG, X. Oral and written story composition skills of children with language impairment. J. Speech Lang. Hear. Res., Rockville, v. 47, n. 6, p. 1301-1318, dez. 2004.

GERALDI, J, W. Palavras escritas, indícios de palavras ditas. Ling. (Dis)curso, Tubarão, v. 3, n. especial, p. 9-25, 2003.

GILLAM, R. B.; JOHNSTON, J. R. Spoken and written language relationships in language/learning-impairment and normally achieving school-age children. J. Speech Hear. Res., Rockville, v. 35, n. 6, p. 1303-1315, dez. 1992.

GONÇALVES, F.; DIAS, M. G. B. B. Coerência textual: um estudo com jovens e adultos. Psicol. Refl. Crít., Porto Alegre, v. 16, n. 1, p. 29-40, jan.-abr. 2003.

KADERAVEK, J. N.; SULZBY, E. Narrative production by children with and without specific language impairment: oral narratives and emergent readings. J. Speech Lang. Hear. Res., Rockville, v. 43, n. 1, p. 34-49, fev. 2000.

KOCH, I. V. O texto e a construção dos sentidos. São Paulo: Contexto, 2003.

KOCH, I. G. V.; TRAVAGLIA, L. C. Texto e coerência. São Paulo: Cortez, 2003.

LILES, B. Z.; DUFFY, R. J.; MERRITT, D. D.; PURCELL, S. L. Measurement of narrative discourse ability in children with language disorders. J. Speech Hear. Res., Washington, v. 38, n. 2, p. 415-425, abr. 1995.

MARANHE, E. A . Ensinando categorias estruturais de história a crianças com dificuldade de aprendizagem. 2004. 139 f. Tese (Doutorado em Educação do Indivíduo Especial) - Centro de Educação e Ciências Humanas, Universidade Federal de São Carlos, São Carlos.

MEDEIROS, J. G.; SILVA, R. M. F. Efeitos de teste de leitura sobre a generalização em crianças em processo de alfabetização. Psicol. Refl. Crít., Porto Alegre, v. 15, n. 3, p. 587-602, set.-dez. 2002.

MONNERAT, R. S. N. Possibilidades discursivas do E: um marcador coringa. Ling. (Dis)curso., Tubarão, v. 4, n. 1, p. 185-203, jul.-dec. 2003.

MUÑOZ, M. L.; GILLAM, R. B.; PEÑA, E. D.; GULLEYFAEHNLE, A. Measures of language development in fictional narratives of Latin children. Language, Speech Hear. Serv. Schools, Rockville, v. 34, n. 4, p. 332-342, out. 2003.

NATHAN, L.; STACKHOUSE, J.; GOULANDRIS, N.; SNOWLING, M. J. The development of early skills among children with speech difficulties: a test of the "critical age hypothesis". J. Speech Lang. Hear. Res., Rockville, v. 47, n. 2, p. 377-391, abr. 2004.
NORBURY, C. F.; BISHOP, D. V. M. Narrative skills of children with communication impairments. Int. J. Lang. Comm. Dis., Londres, v. 38, n. 3, p. 287-313, jul.-set. 2003.

OETTING, J. B.; HOROHOV, J. E. Past-tense marking by children with and without specific language impairment. $J$. Speech Lang. Hear. Res., Rockville, v. 40, n. 1, p. 62-74, fev. 1997.

PADOVANI, C. M. C. A .; COSTA, E. A.; Silva, L. P. A. Efeito do contexto sociocultural na compreensão da linguagem oral. Soc. Bras. Fonoaudiol., São Paulo, v. 9, n. 3, p. 151-155, jul.-set. 2004.

PINHEIRO, C. L. Integração de fatos formulativos e interacionais na construção do texto: um estudo sobre o uso de formas referenciais na organização tópica. Ling. (Dis)curso., Tubarão, v. 4, n. 1, p. 37-64, jul.-dec. 2003.

SANTOS, M. T. M.; NAVAS, A . L. G. P. Distúrbios de Leitura e Escrita: teoria e prática. Barueri: Manole, 2002.

SAYEG-SIQUEIRA, J. H. O texto - movimentos de leitura, táticas de produção, critérios de avaliação. São Paulo: Selinunte, 1990.

SCOTT C. M.; WINDSOR, J. General language performance measures in spoken and written narrative and expository discourse of school-age children with language learning disabilities. J. Speech Lang. Hear. Res., Rockville, v. 43, n. 2, p. 324-339, abr. 2000.

SHIRO, M. Genre and evaluation in narrative development. J. Child Lang., London, v. 30, p. 165-195, 2003.

SNOWLING, M. Language skills and learning to read: literacy outcomes for children at high-risk of reading difficulties. In: DAI - EUROPEAN CONFERENCE, 17 abr. 2004, Dublin (Irland). Dublin: Dyslexia Association of Triland. Avaliable at <http://www.dyslexia.ie/ Snowling\%20Conference\%202004.pdf $>$. Access: 12 feb. 2006.

SOUZA, O. C. Construindo histórias: quando - então depois, marcadores aspectuo-temporais em narrativas de crianças. Lisboa: Editora Estampa, 1996.

SPINILlO, A. G.; MARTINS, R. A. Uma análise da produção de histórias coerentes por crianças. Psicol. Refl. Crít., Porto Alegre, v. 10, n. 2, p. 219-248, maio-ago. 1997.

SPINILLO, A. G.; SIMÕES, P. U. O desenvolvimento da consciência metatextual em crianças: questões conceituais, metodológicas e resultados de pesquisas. Psicol. Refl. Crít., Porto Alegre, v. 16, n. 3, p. 537-548, set.-dez. 2003.

STORCH, S. A.; WHITEHURST, G. J. Oral language and code-related precursors to reading: evidence from a longitudinal structural model. Dev. Psychol., Washington, v. 38, n. 6, p. 934-947, nov. 2002.

STRONG, C. J.; SHAVER, J. P. Stability of cohesion in the spoken narratives of language-impairment and normally developing school-aged children. J. Speech Hear. Res., Washington, v. 34, n. 1, p. 95-11, fev. 1991.

WINDSOR, J.; SCOTT, C. M.; STREET, C. K. Verb and noun morphology in the spoken and written language of children with language learning disabilities. J. Speech Hear. Res., Washington, v. 43, n. 6, p. 1322-1336, dez. 2000. 